\title{
Behavioral aspects of Santa Inês sheep kept in pasture in a tropical rainforest climate
}

\section{Maria Cristina Manno ${ }^{*}$ iD Luiz Fernando de Souza Rodrigues ${ }^{1}$ Kedson Raul de Souza Lima $^{1}$ Monique Valéria de Lima Carvalhal ${ }^{2}$ iD Silas Santiago Rodrigues Filho ${ }^{1}$ Gleyce Lopes da Costa ${ }^{1}$ Ailime Nayara Gomes Monteiro ${ }^{1}$ Andrea do Nascimento Barreto ${ }^{1}$}

${ }^{1}$ Instituto da Saúde e Produção Animal, Universidade Federal Rural da Amazônia (UFRA), 66077-830, Belém, PA, Brasil. E-mail: mannomc@gmail.com. ${ }^{*}$ Corresponding author.

${ }^{2}$ Programa de Pós-graduação em Zootecnia, Departamento de Zootecnia, Faculdade de Ciências Agrárias e Veterinárias, Universidade Estadual Paulista (UNESP), Jaboticabal, SP, Brasil.

\begin{abstract}
This study aimed to evaluate behavioral aspects of Santa Inês sheep in pasture in humid tropical climate. In order to do so, nine Santa Inês sheep were kept on pasture, exposed to the climate directly, without shade, for 24 days, with 12 alternate days in each period (dry and raining) in 2015. The behavioral parameters evaluated were: food consumption, standing idleness, lying idle and rumination. Observations occurred from 08:00 A.M. to 05:55 P.M. The experimental was a completely randomized design (CRD) with two treatments (rainy season and dry period), nine replications, one animal per experimental unit. To understand the correlations of the behavioral parameters with the climatic variables, Pearson's correlation was performed. Approximate average values between the rainy and dry periods for the behavioral variables were observed, but there was a greater intake in the volume of water in the dry period (9.59L/sheep). Also, there were significant differences in the behavior of the animals throughout the day. In the hottest time of the day, at 02:00 P.M., there was standing idle of 25.83min., lying idle of 1.21min., and spent less time-consuming food (27.08min.) in relation to other schedules. We concluded that the sheep had similar behavioral parameters in the rainy and dry periods, but when we observe the times of the days, the behaviors are different. The main activity recorded was grazing, and the variables, temperature and relative humidity of the air influence differently between the seasons, being more marked in the dry period.

Key words: dry season, raining season, grazing.
\end{abstract}

Aspectos comportamentais de ovinos da raça Santa Inês mantidos em pasto em clima tropical úmido

RESUMO: Este estudo objetivou avaliar aspectos comportamentais de ovinos Santa Inês criados em pasto em clima tropical úmido. Para tanto, foram utilizados nove carneiros Santa Inês, mantidos a pasto, expostos diretamente ao clima, sem sombra, durante 24 dias, sendo 12 dias alternados em cada período (seco e chuvoso) em 2015. Os parâmetros comportamentais avaliados foram consumo de alimento, ócio em pé, ócio deitado e ruminação. As observações ocorreram das 08:00h às 17h:55min. O delineamento experimental foi o inteiramente casualizado (DIC) com dois tratamentos (periodo chuvoso e periodo seco), nove repetições, um animal por unidade experimental. Para entender as correlações dos parâmetros comportamentais com as variáveis climáticas foi realizada a correlação de Pearson. Foram observados valores médios gerais aproximados entre os periodos chuvoso e seco para as variáveis comportamentais, porém, houve maior ingestão no volume de água no periodo seco (9,59L/ovino). Também, ocorreu diferença no comportamento dos animais ao longo do dia. No horário mais quente do dia, das 14 hàs 15 h, registrou-se ócio em pé de 25,83min. e ócio deitado de 1,21min., e os animais passaram menor tempo consumindo alimento (27,08min.) em relação aos demais horários. Podemos concluir que os ovinos apresentaram parâmetros comportamentais semelhantes nos periodos chuvoso e seco, porém, quando observamos os horários dos dias, os comportamentos são diferentes. A principal atividade registrada foi o pastejo. As variáveis temperatura e a umidade relativa do ar influenciam de forma diferente o comportamento dos ovinos entre as estações do ano, sendo mais marcantes no período seco.

Palavras-chave: estação seca, estação chuvosa, pastejo.

\section{INTRODUCTION}

Sheep farming is an activity of great social and economic importance in Brazil. It represents a good alternative for Brazilian agribusiness (LEITÃO et al., 2013). Despite the increase in production and consumption of the products from the sheep industry in the country, when compared on a world scale, the production rates are still low. Genetic potential of herds, seasonality in production, tropical forage quality, climate, management, calving interval, age at first calving, and disease control are some of the factors that limit the productivity of the sheep industry. 
The key point for a sheep production system sustainable that guarantees the welfare of the animals is the planning of a management that meets their needs. In other words, it is fundamental to expand the knowledge related to the adaptive characteristics strategies of the animals before making any changes in the rearing systems and management, in order to adapt technical recommendations to the specific needs of this species (PARANHOS DA COSTA, 1992; BROOM, FRASER, 2010). In the extensive rearing system, in which the animals spend most part of the day grazing, different behavioral activities occur. These activities may be influenced by factors related to the environment, pasture characteristics, management practices, supply of food supplementation, group activities of the animals and climatic conditions (SEJIAN et al., 2012). In addition, grass-fed animals in tropical regions are more challenged, because the environmental temperature values and relative humidity may exceed the ideal thermal comfort for the performance of most animal species (COSTA et al., 2014).

The influence of climate elements may be considered one of the main challenges of the production system. The animal tries to adapt its behavior to the weather conditions, what can compromise one of the most important activities that is grazing. So, under the production point of view, the factors that influence and result in a bigger grazing time are significant for the animal performance (SIQUEIRA; FERNANDES, 2014). The tropical environment, highlighted by high temperature and relative air humidity, might influence the standard ingestive behavior of sheep (SILVA et al., 2014). However, there are still few records of the direct influence of the Af climate type over the behavior of sheep, what can be considered a limiting factor for a pasture-based rearing system of these animals. Therefore, the objective of this research was to evaluate the action of the Af climate type (ALVARES et al., 2013), over the dry and raining season, on the behavioral parameters of grazing Santa Inês reed sheep.

\section{MATERIALS AND METHODS}

\section{Animals and management}

Nine male Santa Inês sheep with black coat-color were used, average weight was $32.5 \mathrm{~kg} \pm 3.5$ and average age of one year old. The experimental research was carried out in 2015 at facilities of the Goats and Sheep Research Center of Pará (CPCOP), located at the Universidade Federal Rural da Amazônia (UFRA), in Belém-PA, metropolitan mesoregion of the State of Pará. The type of climate is Af (Tropical rainforest climate), with average annual temperatures above $26^{\circ} \mathrm{C}$, between 3,000 and $4,000 \mathrm{~mm}$ of rainfall (ALVARES et al., 2013). From December to May, there is a greater intensity of rainfall (raining season), and between June and November, a period with a lower rainfall intensity is observed (MARTORANO et al., 1993). Animals had no shade, either natural or artificial, inside the paddocks, being directly exposed to the climatic conditions of the region.

Sheep were kept in an area of 1.8 ha, with Massai Grass (Panicum maximum cv. Massai), divided into four paddocks of approximately $0.45 \mathrm{ha}$ each. Animals were raised under rotational grazing system, with a fixed period of occupation of seven days and resting of 21 days, where they had access of a grazing area from 08:00 A.M. at 06:00 P.M. At the end of the day (at 06:00 P.M.), the animals would be guided to the herd where they did not have access to the pasture and were given grinded roughage (Pennisetum purpureum cv. Elephant grass) and 200 grams of concentrate containing $51 \%$ corn, $30 \%$ soybean meal, $18 \%$ wheat bran and $1 \%$ calcitic limestone, in order to meet daily maintenance needs. Water and mineral salt were supplied ad libitum. In order to estimate the total forage availability, grass samples were collected in each experimental period using a wood square of $0.25 \mathrm{~m}^{2}(0.5 \times 0.5)$ thrown in the pasture, being all the material collected from its inside and repeated in each paddock before the entrance of the animals and in the day of observing grazing behavior. Later the samples were weighed, packed in plastic bags, identified and frozen for posterior analysis of chemical composition of the forage fed to the animals. In addition, with the help of a ruler of $50 \mathrm{~cm}$ in length, the heights of the lawn and of the residue were measured. Data can be seen in table 1.

\section{Treatments and experimental period \\ Two treatments were evaluated,} RAINING (T1) considered the season (period) of the year with greater predominance of rainfall, and DRY (T2) season (period) with less rainfall, according to the common rainfall regime of the region (MARTORANO et al., 1993). The research was carried out from March $2^{\text {nd }}$ to April $10^{\text {th }}(\mathrm{T} 1)$ and from Aug. $17^{\text {th }}$ to Sept. $25^{\text {th }}$ (T2) of 2015, defined based on the data obtained from the meteorological station of Belém (Instituto Nacional de MeteorologiaINMET; $2^{\circ}$. District of Meteorology $-2^{\circ}$ DISME) in 2014. The observation period for data recording was 12 alternate days, in both treatments, and before being started, the animals went through a 
Table 1 - Chemical composition of grass (Panicum maximum cv. Massai) grazed by Santa Inês sheep in Belém - PA.

\begin{tabular}{|c|c|c|c|c|c|c|c|}
\hline Season & $\begin{array}{l}\text { Lawn height } \\
(\mathrm{cm})\end{array}$ & $\begin{array}{l}\text { Residue height } \\
(\mathrm{cm})\end{array}$ & $\begin{array}{l}\text { Forage mass } \\
\quad\left(\text { ton } \mathrm{ha}^{-1}\right)\end{array}$ & $\% \mathrm{DM}$ & $\%$ NDF (DM) & $\% \mathrm{ADF}(\mathrm{DM})$ & $\%$ CP (DM) \\
\hline Dry $^{1}$ & 24.9 & 18 & 6.0 & 33.5 & 60.7 & 42.1 & 5.9 \\
\hline Raining $^{2}$ & 25.2 & 19 & 11.7 & 27.4 & 72.2 & 46.9 & 5.3 \\
\hline
\end{tabular}

${ }^{1}$ March to April of 2015; ${ }^{2}$ Agust to September of 2015.

period of adaptation to the environment and to the management routine for 15 days.

For recording climatic variables (air temperature $\left(\mathrm{T}^{\circ} \mathrm{C}\right)$, relative air humidity $(\mathrm{RH})$, air velocity (Av), and rainfall (Rf)), was used a meteorological station (INCOTERM - NEXUS Funk Wetterstation). With the use of analog equipment, the dry bulb temperature (Tbs), the wet bulb temperature (Tbu) and the black globe temperature (Tgn) were obtained.

The recording of behavioral variables was performed twice a week in the periods assigned to each treatment. Observation time for recording the data was from 08:00 A.M. to 05:55 P.M., that was the time the animals were released on the paddock, being managed by three trained observers, on a relay scale during the periods of observation $\left(1^{\text {st }}\right.$ watch 08:00 A.M. to 12:00 P.M.; $2^{\text {nd }}$ watch - 12:00 P.M. to 03:00 P.M.; and $3^{\text {rd }}$ watch 03:00 P.M. to 06:00 P.M.). Rumination time, idleness (standing and lying) and feed intake categories were observed at a regular five-minute interval, when all animals were evaluated for the variety of behavior presented (BROOM; FRASER, 2010).

For the analysis of water volume ingested, on the days of observation of the behavioral parameters, the amount of water that the animals consumed was recorded through the volume of water deposited in a graduated container that was in the pasture. The volume of water ingested by the animals was computed by the difference between the water supplied at the beginning of each observation period and at the end of the observation period, when water from the drinking fountains was renewed. In order to ensure that there was no distortion of this index according to the rainfall regime on the days of behavior observation, a control vessel was kept in one paddock without animal access, in order to control the amount of water that was added coming from the rain, as well as the evaporation of water on days of lower relative air humidity.

\section{Statistics analysis}

The experimental was in a completely randomized design with two treatments (raining season and dry season), nine replicates with one animal per experimental unit. Grazing behavior data were computed in average of minutes of each variable per hour of observation and submitted to the Kolmogorov-Smirnov normality test. The data of regular behavior (parametric) were submitted to Analysis of Variance (ANOVA) and, if significant, the means were compared by the Tukey test at $5 \%$ of probability. In the case of nonparametric data, was utilized the Kruskal-Wallis test that is a oneway analysis of variance. Correlations of behavioral parameters with climatic variables using Pearson's correlation were analyzed and significant data were submitted to orthogonal decomposition of sum of the squares of the treatments in linear, quadratic, cubic and quartic order, with posterior adjustment of linear regressions. All statistical proceedings were analyzed using SAS (version 9.0).

\section{RESULTS}

\section{Behavior over the seasons of the year}

Temperature and relative air humidity data were collected during the experimental period through a meteorological station and analog equipment installed in the paddocks, that recorded that the animals were submitted from 08:00 A.M. to 06:00 P.M. to the average temperature of $29^{\circ} \mathrm{C}$ during the raining season, being lower $(\mathrm{P}<0.05)$ than the temperature in the dry season, with average of $33.8^{\circ} \mathrm{C}$. However, the relative air humidity varied, being lower $(\mathrm{P}<0.05)$ in the dry season $(57.7 \%)$ when compared with the raining season $(78.4 \%)$, which corroborates 
to the rainfall data collected in the same period $(9 \mathrm{~mm}$ versus $560 \mathrm{~mm}$ during the data collection period). The average for air velocity registered in those intervals were of $4.0 \mathrm{~m} / \mathrm{s}$ on the dry season and $1.27 \mathrm{~m} / \mathrm{s}$ on the raining season.

Over both periods of the year, in average, the animals spent $66.2 \% \pm 27.1$ of the time feeding (FI - grazing), 21.3\% \pm 19.8 in idle (SI - standing), $1.6 \% \pm 2.4$ in idle (LI - lie down) and $10.8 \% \pm 15.2$ of rumination time (RT) (Table 2). In both observed periods, the behavior parameters registered presented approximate values, and the main activity was grazing, totaling on average of $6.62 \mathrm{~h} /$ day.

During the raining season, the main climate variables that influenced to decrease or interrupt grazing (feeding, FI) was the air velocity (Av) and rainfall (Rf) (Table 3). Due to the influence of $\mathrm{Rf}$ $(\mathrm{mm})$, it was observed a reduction or interruption of grazing in order to ruminate. Moreover, with the high intensity of rain, it was noticed that sheep would stay idle. And with the low intensity, animals would be seen in idleness and ruminating. When the rain was over, slowly the animals would start grazing again.

During the dry season, climate variables that had more influence, mostly in grazing, were temperature and relative air humidity. With an increase of the $\mathrm{T}\left({ }^{\circ} \mathrm{C}\right)$, animals stopped grazing and stood in idleness; however, by influence of the RH $(\%)$, there was a decrease in idleness and grazing was registered.

\section{Pattern of behavior over the main hours of the day}

There's a variation of the activities throughout the day (Table 4). In the mornings, 08:00 A.M. and 11:00 A.M., animals spend more time eating than in the afternoon, 02:00 P.M. and 05:00 P.M., totaling 100.31 and 58.25 minutes, respectively.
In the afternoon, was registered more idleness, standing idle (41.62 minutes), lying idle (2.09 minutes) and rumination time (19.38 minutes), with higher interruption of grazing and rumination in the afternoon, mainly during 02:00 P.M.

By regression analysis, feeding showed a significant quadratic trend, showing a minimum point at $03 \mathrm{~h} 45$ P.M., when the animals presented, on average, 25 minutes of grazing per hour. In general, climatic variables that influence on animals' activities is mainly air temperature and rainfall (Table 5), with an increase in temperature, was registered standing idle, and with rainfall it was observed a decrease or an interruption of grazing.

A higher water intake on the dry season was observed, being different $(\mathrm{P}<0.05)$ from the raining season. In general, animals would drink more water in the afternoons, being different $(\mathrm{P}<0.05)$ from mornings.

\section{DISCUSSION}

\section{Behavior over the seasons of the year}

Percentage of time spent by the animals doing the recorded activities during the two periods of the year was similar. What can be attributed to the fact that the animals developed behavioral patterns according to the environmental conditions in which they are kept, that is, these animals have the ability to adjust their behavior in pasture (LIN et al., 2011; SEJIAN et al., 2012). Our results showed that after grazing, possibly due to an increase in the raining intensity (raining season) or the air temperature (dry season) animals remained in idleness; what can justify that in the raining season we found a negative correlation for $\mathrm{FI}$ and $\mathrm{Rf}$ $(\mathrm{mm})(-0.36518)$ and in the dry season a negative

Table 2 - Total percentage time, showing behavior parameters ( $\mathrm{FI}=$ Feeding, $\mathrm{SI}=$ standing idle, $\mathrm{LI}=$ lying idle, $\mathrm{RT}=$ rumination time) in sheep exposed to the Amazonian climate* during the raining and dry periods.

\begin{tabular}{lcccccc}
\hline Parameters & Raining Season & Dry Season & Mean and SD & CV & Min./day & Hours/day \\
\hline FI & $66.30 \%$ & $65.98 \%$ & $66.2 \% \pm 27.1$ & $41,0 \%$ & 397.1 & 6.63 \\
SI & $21.30 \%$ & $21.43 \%$ & $21.4 \% \pm 19.8$ & $92.7 \%$ & 128.0 & 2.13 \\
LI & $1.80 \%$ & $1.53 \%$ & $1.6 \% \pm 2.4$ & $146.3 \%$ & 9.9 & 0.16 \\
RT & $10.60 \%$ & $11.06 \%$ & $10.8 \% \pm 15.2$ & $140.1 \%$ & 65.0 & 1.08 \\
Total & $100 \%$ & $100 \%$ & $100 \%$ & 600 & 10 \\
\hline
\end{tabular}

*tropical rainforest climate. 
Table 3 - Correlation coefficients between the climatic variables $(\mathrm{T}=$ air temperature, $\mathrm{RH}=$ relative air humidity, Av=air velocity, $\mathrm{Dp}=\mathrm{dew}$ point temperature, $\mathrm{Rf}=$ rainfall) and behavioral parameters $(\mathrm{FI}=$ feeding/grazing, $\mathrm{SI}=$ standing idle, $\mathrm{LI}=$ lying idle, $\mathrm{RT}=\mathrm{rumination}$ time) on the raining and dry periods.

\begin{tabular}{|c|c|c|c|c|}
\hline Climate Variables & FI & SI & LI & RM \\
\hline \multicolumn{5}{|c|}{ } \\
\hline $\mathrm{T}\left({ }^{\circ} \mathrm{C}\right)$ & 0.12958 & 0.08984 & 0.08890 & $-0.33618^{*}$ \\
\hline RH $(\%)$ & -0.04595 & $-0.20821^{*}$ & -0.1716 & $0.35130^{*}$ \\
\hline $\operatorname{Av}(\mathrm{m} / \mathrm{s})$ & $-0.23173^{*}$ & $0.22026^{*}$ & 0.10207 & 0.09860 \\
\hline $\mathrm{Dp}\left({ }^{\circ} \mathrm{C}\right)$ & $0.20154^{*}$ & -0.00507 & 0.09351 & $0.33663^{*}$ \\
\hline $\operatorname{Rf}(\mathrm{mm})$ & $-0.36518^{*}$ & -0.03043 & -0.16389 & $0.65170^{*}$ \\
\hline \multicolumn{5}{|c|}{ 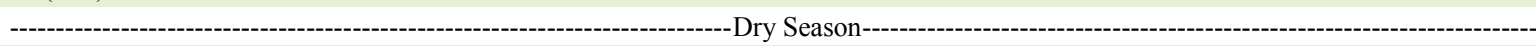 } \\
\hline $\mathrm{T}\left({ }^{\circ} \mathrm{C}\right)$ & $-0.32421^{*}$ & $0.45450^{*}$ & $0.25642^{*}$ & -0.02808 \\
\hline RH (\%) & $0.46178^{*}$ & $-0.51398^{*}$ & $-0.36236^{*}$ & -0.14817 \\
\hline $\operatorname{Av}(\mathrm{m} / \mathrm{s})$ & 0.17806 & -0.15727 & -0.16904 & -0.09661 \\
\hline $\mathrm{Dp}\left({ }^{\circ} \mathrm{C}\right)$ & 0.10021 & 0.07393 & -0.07931 & $-0.29309^{*}$ \\
\hline $\mathrm{Rf}(\mathrm{mm})$ & -0.07759 & -0.08533 & -0.05446 & $0.27795^{*}$ \\
\hline
\end{tabular}

${ }^{*} \mathrm{P}<0.05$.

correlation with air temperature $(-0.32421)$. These results disagree with those reported by SANTOS et al. (2011), that observed lambs of Santa Inês breed, and after grazing they showed being in rumination time. Study showed that climatic elements may define the weather of the tropical regions are the pluviometric regime and the relative air humidity (VIEIRA et al., 2008) and the pluviometric regime not only influences directly the thermoregulation and availability of food, but also the feeding behavior of animals (PEREIRA, 2005).

In the dry season, a negative correlation was observed for the variable feed intake with air temperature (-0.32421) and positive (0.46178) with relative air humidity (Table 3 ), suggesting that these environmental conditions may not favor the grazing behavior in sheep. As described by BROOM and FRASER (2010), in high temperature animals stop

Table 4 - Mean values, standard deviation by seasons (raining and dry), by time of day (08:00 a.m., 11:00 a.m., 02:00 p.m. and 05:00 p.m.), regression equations of behavioral parameters $(\mathrm{FI}=$ feed intake, $\mathrm{SI}=$ standing idle, $\mathrm{LI}=$ lying idle, $\mathrm{RT}=$ rumination time) and water intake (WI) in the raining and dry seasons.

\begin{tabular}{|c|c|c|c|c|c|c|}
\hline Parameters & $\mathrm{n}$ & $\mathrm{FI}^{*}(\min )$. & $\mathrm{SI}^{*}$ (min.) & $\mathrm{LI}^{*}$ (min.) & RT (min.) & WI (liter.) \\
\hline Mean values and SD & 240 & $39.7 \pm 16.3$ & $12.8 \pm 11.8$ & $1.05 \pm 1.4$ & $6.5 \pm 9.07$ & \\
\hline Raining & 120 & 39.74 & 12.75 & 1.11 & 6.35 & $5.28 \mathrm{~B}$ \\
\hline Dry & 120 & 39.71 & 12.92 & 0.99 & 6.65 & $9.59 \mathrm{~A}$ \\
\hline 08:00 a.m. & 240 & 59.08 & 0.67 & 0.25 & 0.04 & \multirow{2}{*}{$2.82 \mathrm{~B}$} \\
\hline 11:00 a.m. & 240 & 41.29 & 10.5 & 1.17 & 7.29 & \\
\hline 02:00 p.m. & 240 & 27.08 & 25.83 & 1.21 & 6.08 & \multirow[b]{2}{*}{$4.61 \mathrm{~A}$} \\
\hline 05:00 p.m. & 240 & 31.17 & 15.79 & 0.88 & 13.3 & \\
\hline
\end{tabular}

${ }^{*} \mathrm{P}<0.05$. Means followed by the same letter in the column do not differ from each other by the Tukey test at the $5 \%$ probability level. Regression equation $-\mathrm{y}=0.57 \mathrm{x}^{2}-17.86 \mathrm{x}+165.65-\mathrm{R}^{2}=0.5467(\mathrm{FI}), \mathrm{y}=-0.55 \mathrm{x}^{2}+15.82 \mathrm{x}-92.14-\mathrm{R}^{2}=0.4602(\mathrm{SI})$ e $\mathrm{y}=-0.03 \mathrm{x}^{2}+0.93 \mathrm{x}-$ $4.95-\mathrm{R}^{2}=0.0881(\mathrm{LI})$. 
Table 5 - Correlation coefficients between the climatic variables $(\mathrm{T}=$ air temperature, $\mathrm{RH}=$ relative air humidity, Av=air velocity, $\mathrm{Dp}=\mathrm{dew}$ point temperature, $\mathrm{Rf}=$ rainfall, $\mathrm{THI}=$ temperature-humidity index, $\mathrm{BGHI}=\mathrm{Black}$ globe-humidity index and parameters of behavior $(\mathrm{FI}=$ feed intake, $\mathrm{SI}=$ standing idle, $\mathrm{LI}=$ lying idle, $\mathrm{RT}=$ rumination time).

\begin{tabular}{|c|c|c|c|c|}
\hline \multirow[t]{2}{*}{ Climatic variables } & \multicolumn{4}{|c|}{ - } \\
\hline & FI & SI & LI & RT \\
\hline $\mathrm{T}\left({ }^{\circ} \mathrm{C}\right)$ & -0.06712 & $0.21026^{*}$ & 0.10327 & $-0.15682^{*}$ \\
\hline RH (\%) & $0.13970^{*}$ & $-0.25030^{*}$ & $-0.14919^{*}$ & 0.08356 \\
\hline $\operatorname{Av}(\mathrm{m} / \mathrm{s})$ & 0.00905 & 0.00498 & -0.06218 & 0.00347 \\
\hline $\mathrm{Dp}\left({ }^{\circ} \mathrm{C}\right)$ & 0.12132 & 0.03517 & 0.01329 & $-0.27593^{*}$ \\
\hline $\mathrm{Rf}(\mathrm{mm})$ & $-0.24662^{*}$ & -0.03448 & -0.11558 & 0.49474 \\
\hline THI & -0.16518 & $0.35212^{*}$ & 0.20516 & -0.05276 \\
\hline BGHI & 0.11059 & 0.27495 & 0.18308 & $-0.27678^{*}$ \\
\hline
\end{tabular}

${ }^{*} \mathrm{P}<0.05$.

their activities and become gasping for breath. In this way, the air temperature is a climatic variable that has a direct influence on the grazing behavior. Besides that, in this period of the year was registered the higher $(\mathrm{P}<0.05)$ water intake (on average 9.59L/ lamb/day, $81.6 \%$ higher than the value recorded on the raining period that was $5.28 \mathrm{~L} / \mathrm{lamb} /$ day), a fact that can be attributed mainly to the high temperatures observed in this same period, with peaks of $38^{\circ} \mathrm{C}$. The negative correlation of FI and RT with $\mathrm{T}\left({ }^{\circ} \mathrm{C}\right)$ and positive with SI (Table 5) indicates that the animals stopped consuming food and remained standing in as an attempt to thermoregulate themselves, drinking more water to help stop the evaporative losses (by sweating and gasping for breath) due to the stressful conditions of heat observed during this period. Water plays a key role in the thermoregulation of animals in those situations, since ingestion is a fast and efficient method to reduce the body temperature of an animal, attenuating the heat through physiological processes such as sweating and urination (MADER, DAVIS, 2001).

Finally, temperature influence and relative air humidity are factors that have a direct effect on the behavior grazing animals at different periods of the year (McMANUS et al., 2009). Effects of temperature, relative air humidity and rainfall mainly interfered on the grazing behavior of the animals, causing adjustments on feed intake (WEST, 2003), triggering mostly idleness, as observed in this study.

\section{Pattern of behavior over the main hours of the day The pattern of behavior during daytime observed in sheep is in agreement with what was}

observed by OLIVEIRA et al. (2013), in which they describe that the peak of grazing are at the beginning and at the end of the day.

Higher feed intake was registered at 08:00 A.M., 11:00 A.M. and 05:00 P.M. (Table 4), for both periods of the year, possibly because at that time of the day the air temperature and relative air humidity did not appear so adverse that these climatic conditions may result in a lower rate of caloric intake (SILVA et al., 2014; PEREIRA, 2005). In addition, it was observed that after 11:00 P.M., sheep often walked through the pasture, and also increased water intake or would stay in idleness (BERGGREN-THOMMAS; HOHENBOKEN, 1986).

Decrease in FI and the establishment of idle time at 02:00 P.M., mostly on the dry season, may be due to the fact that sheep would try to activate mechanisms of heat loss and reduce the production of metabolic heat, that is, to interrupt their grazing activities trying to dissipate excess heat (SILANIKOVE, 2000). These results agree with those observed by PARENTE et al. (2007), in a study conducted with Santa Inês sheep in Teresina, Piauí State, using different categories of animals, they observed that the three categories under study were idle at the hottest hours of the day.

In the same way, the higher water intake was at 02:00 P.M. to 05:00 P.M. $(4,61 \mathrm{~L} / \mathrm{lamb}$ in the afternoon, vs $2,82 \mathrm{~L} / \mathrm{lamb}$ in the morning), it may be explained by the increase of the air temperature and the high humidity at those hours. The search for water becomes one of the most efficient alternatives to reduce the body temperature at this hour, 
mitigating the harmful effects of heat, while their scarcity or deprivation compromises animal welfare (ORTÊNCIO FILHO et al., 2001).

Rumination is mostly registered at 05:00P.M., being this moment when the peaks of this activity happen for this species. It was observed that animals focused this activity at the end of the period that they were grazing, being able to do so not only because they spent most of the time eating feed, but alto because it was near to nighttime when, according to ANIMUT et al. (2005), sheep ruminate and rest mainly at night.

\section{CONCLUSION}

Behavioral parameters of the sheep were similar in both raining and dry seasons, but the animals presented different behaviors during the day in the different periods of the year. The main activity of the animals is grazing followed by idleness. Air temperature correlates negatively with feed intake on the dry season, being rainfall and high relative air humidity parameters that limit feed intake during the raining season, leading the animals to idleness in the afternoon in both periods. Sheep producers in a tropical humid climate need to invest in environmental modifications in order to minimize the negative impact of high temperatures and relative air humidity on the performance of grazing sheep.

\section{BIOETHICS AND BIOSSECURITY COMMITTEE APPROVAL}

The Comitê de Ética em Uso de Animais from Universidade Federal Rural da Amazônia (CEUA/UFRA, protocol 002/2015) approved the proceedings with the animals.

\section{DECLARATION OF CONFLICTING INTERESTS}

The authors declare no conflict of interest. The founding sponsors had no role in the design of the study; in the collection, analyses, or interpretation of data; in the writing of the manuscript, and in the decision to publish the results.

\section{AUTHORS' CONTRIBUTIONS}

The authors contributed equally to the manuscript.

\section{REFERENCES}

ALVARES, C.A. et al. Köppen's climate classification map for Brazil. Meteorologische Zeitschrift, v.22, p.711-728, 2013. Available from: $\quad<$ https://dx.doi.org/10.1127/0941-2948/2013/0507> Accessed: Jan. 10, 2015. doi: 10.1127/0941-2948/2013/0507.
ANIMUT, G. et al. Grazing behavior and energy expenditure by sheep and goats co-grazing grass/forb pastures at three stocking rates. Small Ruminants Research, v.59, p.191-201, 2005. Available from: $<$ https://doi.org/10.1016/j.smallrumres.2005.05.014>. Accessed: Feb. 10, 2015. doi: 10.1016/j.smallrumres.2005.05.014.

BERGGREN-THOMMAS, B.; HOHENBOKEN, W. D. The effects of sire-breed, forage availability and weather on the grazing behaviour of crossbreed ewes. Applied Animal Behavior Science, v.15, n.3, p.217-228, 1986. Available from: <https://doi. org/10.1016/0168-1591(86)90092-4>. Accessed: Jan. 20, 2015. doi: 10.1016/0168-1591(86)90092-4.

BROOM, D.M., FRASER, A.F. Comportamento e bem-estar de animais domésticos. Barueri - SP: Manole, 2010. $4^{\mathrm{a}} \mathrm{ed}$.

COSTA, J.H.S., et al. Characterization of the thermal environment and adaptability of sheep breeding in native and exotic Paraiba cariri. Green Journal of Agroecology and Sustainable Development, v.9, n.3, 2014, p.350-355.

DETMANN, E. et al. Métodos para Análise de Alimentos - INCT - Ciência Animal. Visconde do Rio Branco: Suprema, 2012. 1ª ed.

LEITÃO, M. V. B. R. et al. Comfort and heat stress in sheep in Northern Bahia. Revista Brasileira de Engenharia Agrícola e Ambiental, v.17, n.12, p.1355-1360, 2013. Available from: <http:// dx.doi.org/10.1590/S1415-43662013001200015>. Accessed: Feb. 15, 2015. doi: 10.1590/S1415-43662013001200015.

LIN, L. et al. Grazing behavior of sheep at different stocking rates in the Inner Mongolian steppe, China. Applied Animal Behavior Science, v.129, n.1, p.36-42, 2011. Available from: <https://doi. org/10.1016/j.applanim.2010.11.002>. Accessed: Nov. 14, 2018. doi: 10.1016/j.applanim.2010.11.002.

McMANUS, C.; et al. Heat tolerance in naturalized Brazilian sheep: physiological and blood parameters. Tropical Animal Health and Production, v.41, p.95-101, 2009. Available from: $<$ https://doi.org/10.1007/s11250-008-9162-1>. Accessed: Jan. 15, 2018. doi: $10.1007 / \mathrm{s} 11250-008-9162-1$.

MADER, T. L.; DAVIS, M. S. Effect of management strategies on reducing heatstress of feedlot steers. Journal of Animal Science, v.79, n.12, p.2941-2948, 2001. Available from: <https:// doi.org/10.2527/2004.82103077x>. Accessed: Jan. 15, 2018. doi: $10.2527 / 2004.82103077 \mathrm{x}$.

MARTORANO, L.G. et al. Estudos climáticos do Estado do Pará, classificação climática (Köppen) e deficiência hídrica (Thornthwaite, Mather). - SUDAM, Belém: EMBRAPA SNLCS, 1993, 53p.

OLIVEIRA, F. A. et al. Physiological parameters of Santa Inês sheep submitted to shaded environment by polypropylene mesh. Revista Brasileira de Engenharia Agrícola e Ambiental, v.17, n.9, p.1014-1019, 2013. Available from: <http://dx.doi. org/10.1590/S1415-43662013000900015>. Accessed: Nov. 13, 2014. doi: 10.1590/S1415-43662013000900015.

ORTÊNCIO FILHO, $\mathrm{H}$. et al. Effect of natural shade and shearing on the behavior of Texel and Hampshire Down sheep during the day period in the northwestern region of Paraná. Acta Scientiarum, v.23, n.4, p.981-993, 2001. Available from: <http:// dx.doi.org/10.4025/actascianimsci.v23i0.2655>. Accessed: Dec. 15, 2014. doi: 10.4025/actascianimsci.v23i0.2655. 
PARANHOS DA COSTA, M. J. R. et al. Effect of air temperature and humidity on ingestive behavior of sheep. Int. J. Biometeorol., Berlin, v.36, p.218-222, 1992.

PARENTE, H. N. et al. Comportamento ingestivo de ovinos em pastagem de tifton-85 (Cynodon sp) na Região Nordeste do Brasil. Revista Ciência Agronômica, v.38, n.2, p.210-215, 2007.

PEREIRA, C.C.J. Fundamentos de bioclimatologia aplicados à produção animal. Belo Horizonte: FEPMVZ, 2005. $1^{\mathrm{a}}$ ed.

SANTOS, M. M. DOS; et al. Behavior of Santa Inês sheep, different colorations, grazing. Acta Scientiarum Animal Sciences, v.33, n. 3, p.287-294, 2011. Available from: <http://dx.doi.org/10.4025/ actascianimsci.v33i3.9974>. Accessed: Jan. 15, 2018. doi: 10.4025/actascianimsci.v33i3.9974.

SEJIAN, V. et al. Effect of walking stress on growth, physiological adaptability and endocrine responses in Malpura ewes in a semi-arid tropical environment. International Journal of Biometeorology, v.56, n.2, p.243-252, 2012. Available from: $<$ http://dx.doi.org/10.1007/s00484-011-0420-y>. Accessed: Dec. 14, 2018. doi: 10.1007/s00484-011-0420-y.

SILANIKOVE, N. Effects of heat stress on the welfare of extensively managed domestic ruminants. Livestock Production Science, v.67, n.1-2, p.1-18, 2000. Available from: $<$ https://doi.
org/10.1016/S0301-6226(00)00162-7>. Accessed: Nov. 14, 2018. doi: 10.1016/S0301-6226(00)00162-7.

SILVA, T. P. D.et al. Ingestive behaviour of grazing ewes given two levels of concentrate. South African Journal of Animal Science, v.45, n.2, 180-187, 2014. Available from: <http://dx.doi. org/10.4314/SAJAS.V45I2.9>. Accessed: Jan. 15, 2018. doi: 10.4314/SAJAS.V45I2.9.

SIQUEIRA, E. R.; FERNANDES, S. Comportamento e Bem-estar de Ovinos em Pastagem. In: SELAIVE, A. B.; OSÓRIO, J. C. S. Produção de Ovinos no Brasil. Brasil: Rocca, 2014. Cap.22, p.379-395.

STATISTICAL ANALYSIS SYSTEM - SAS. SAS System for Windows. Release 8.02. Cary: 2001 (CD-ROM).

VIEIRA, R. J. et al. Influence of scrotal morphology and season on the quality of goat semen raised in Piauí State. Revista Brasileira de Ciências Agrárias, v.3, n.4, p.376-380, 2008. Available from: $<$ http://dx.doi.org/10.5039/agraria.v3i4a236>. Accessed: Dec. 19, 2014. doi: 10.5039/agraria.v3i4a236.

WEST, J.W. Effects of heat stress on production in dairy cattle. Journal of Dairy Science, v.86, p.2131-2144, 2003. Available from: $<$ http://dx.doi.org/10.3168/jds.S0022-0302(03)73803-X>. Accessed: Jan. 07, 2015. doi: 10.3168/jds.S0022-0302(03)73803-X. 